\title{
THE ROLE OF THE SOCIAL POLICY IN CREATING THE IMAGE OF THE REGION (THE CIVIL SOCIETY)
}

\begin{abstract}
The development of particular regions located in the EU member states is intended to establish a strong unified territory that would be co-inhabited by different communities. On the other hand, the harmonious growth of the entire EU is guaranteed by the realization of the regional cohesion policy concerning member states and their regions. Therefore regional policy became a specific area of the EU accession negotiations with Poland.

The level of structural fund absorption in Polish regions has become a focus of attention too. Poland's aim to participate in the realization of common regional policy required adjusting Polish economy, social and local policies to meet the EU standards during the preaccession period. Polish local governments have been obliged to become aware of and adopt a strategic approach to their administrative function and the ability to influence local economies actively. There has been, however, a great diversity in progress that Polish local governments have made in this field, both on a national and regional scale.

Due to the Poland's accession to the European Union the regional economic growth has become a planned and predictable process that is implemented by local governments, civil communities, and private and public sectors through cohesive action, development strategy for every area, and many different programmes and initiatives.
\end{abstract}

Key words: image of the region, social policy, regional policy, public life, civil society 